\title{
Diversifikasi tanaman herbal menjadi produk minuman untuk masyarakat lokal dan wisatawan
}

\author{
Dewa Komang Tantra dan I Wayan Rasna \\ Universitas Pendidikan Ganesha Singaraja, Bali \\ Email: dewatantra@yahoo.com
}

\begin{abstract}
Abstrak
Penelitian ini bertujuan untuk menganalisis tanaman herbal yang termuat pada lontar usadha dan yang digunakan oleh balian di Bali untuk didiversifikasi menjadi minuman siap saji bagi masyarakat lokal atau minuman selamat datang untuk wisatawan. Sampel lontar usadha yang diteliti berjumlah 18, informan balian 15 orang, 20 guru sekolah menengah kejuruan (SMK) pariwisata dan dosen sekolah tinggi pariwisata (STP). Teknik pengambilan sampel dilakukan secara purposif. Data tentang bahan obat yang termuat dalam lontar usadha dikumpulkan dengan teknik telaah isi lontar. Data tentang tanaman obat yang digunakan oleh balian dikumpulkan dengan teknik wawancara mendalam. Sedangkan, data tentang potensi bahan obat tradisionl untuk didiversifikasi menjadi minuman masyarakat lokal dan minuman selamat datang dikumpulkan melalui kuesioner dari para guru SMK dan dosen STP Jurusan Tata Boga. Data yang diperoleh dianalisis secara deskriptif kualitatif. Hasil telaah lontar usadha, wawancara dengan balian, kuesioner dengan guru dan dosen Sekolah Pariwisata ditemukan 20 jenis bahan obat tradisional yang potensial untuk didiversifikasi menjadi minuman siap saji bagi masyarakat lokal atau minuman selamat datang bagi wisatawan.
\end{abstract}

Kata Kunci: lontar usadha, balian, minuman masyarakat, wisatawan

\footnotetext{
Abstract

The purpose of this research was to analyze traditional herbs in the lontar usadha or traditional healing books and those which were frequently used by the traditional healers in Bali. These traditional herbs studied for potential diversification as local society's drink or tourist's wellcome drink. The sample were taken purposively and they consisted
} 
of 18 lontar usadha, 15 balian or traditional healers, and 20 tourism school teachers and lecturers. Data on traditional herbs in the lontar usadha were collected using a content analysis technique. Data on traditonal herbs used by balian or traditional healers were collected through an in-depth interview technique. Whereas, data on traditional herbs are potentially diversified as society's drink and tourist's wellcome drink were collected using a questionnaire. The questionaire was administered to teachers and lecturers of Culiniary Department, School of Tourism in Bali. Data were analyzed descriptively qualitative. The analysis of the lontar usadha's contents, balian's in-depth interview, teachers and lecturers' questionnaire show 20 traditional herbs are potentially diversified as local society's drink or tourist's welcome drink.

Key words: lontar usadha, balian, society's local drink, tourist' wellcome drink

\section{Pendahuluan}

Denelitian ini bertujuan untuk menganalisis bahan obat dari 1 tumbuh-tumbuhan yang termuat pada lontar usadha (teks berisi bahan obat-obatan), digunakan oleh balian atau dukun untuk pengobatan tradisional, dan potensial didiversifikasi sebagai minuman siap saji atau minuman selamat datang untuk konsumsi masyarakat lokal, wisatawan nusantara atau mancanegara. Bahan obat tradisional yang termuat dalam lontar usadha telah dimanfaatkan oleh parabalian (dukun) di Baliuntuk menyembuhkan berbagai penyakit pasien secara tradisional. Di Bali, para dukun memanfaatkan bahan obat yang berasal dari berbagai tananam dan umbi-umbian tersebut dalam bentuk loloh (jamu) atau boreh (parem) (Sukarsa, 2004; Sujana dkk., 2014; Sukerti, 2014).

Selama ini, pemanfaatan bahan obat tradisional berkisar pada penyembuhan penyakit pasien yang didasarkan pada khasiat. Dalam Lontar Tarupramana, obat tradisional dikategorikan menurut khasiat, yaitu anget (hangat), tis (dingin) dan dumalada (sedang, netral). Dalam lontar yang sama disebutkan pula berbagai jenis bahan obat yang berkhasiat anget, tis dan dumalada. Misalnya, daun paya (pare) babakan atau kulit pohon belimbing memiliki khasiat anget. Tanaman yang berkhasiat tis adalah getah awar-awar, akar dan 
buah belego (sebangsa labu), akar dan daun kayu manis. Tanaman yang mempunyai khasiat dumelada, antara lain akar delima, akar kenanga, dan daun sembung (Nala, 2007).

Masih banyak tanaman dan umbi-umbian lainnya dapat ditemukan di Bali. Misalnya, kencur (kaempferia galanga L); temutis (Curcuma purpuracens BL); gamongan = lempuyang (zingiber Cassumianar Roxb), belimbing buluh (Averrhoa bilimbi L); sembung (blumea balsamifera L); kacemcem (spondias pinnata L Anacardiaceae); kunir (Curcuma domestica), tibah (mengkudu = morinda citrifolia $L$ rubiaceae); sirih (piper betle L); belimbing besi (Averrhwa carambola $L$. Oxalidaceae); beras merah (Oryza sativa linn f); dan kayu manis (cnina momum zeyla nicum Ness). Namun, hampir semua jenis tanaman dan umbi-umbian di atas diolah menjadi obat oleh balian (dukun) untuk menyembuhkan pasien atau oleh masyarakat sebagai obat penyembuh penyakit.

\section{Diversifikasi Produk Lontar Usadha}

Pemanfaatan tanaman atau umbi-umbian dalam lontar usadha oleh dukun dan masyarakat masih bisa diversifikasi, bukan hanya sebagai obat, tetapi juga sebagai minuman sehat dan berkhasiat untuk masyarakat dan wisatawan nusantara maupun mancanegara. Diversifikasi pemanfaatan tanaman dan umbi-umbian tradisional bertujuan untuk membiasakan masyarakat mengonsumsi minuman yang sehat, murah dan berakar dari kebudayaannya sendiri (local wisdom). Mengonsumsi minuman sehat dari tanaman obat berkhasiat akan meningkatkan apresiasi mereka terhadap kekayaan alam dan budaya sendiri (Oka, 2002; Nala, 2007).

Pemanfaatan bahan obat tradisional dalam lontar usadha sebagai minuman siap saji akan memberi peluang berusaha kepada masyarakat untuk terlibat dalam usaha ekonomi kreatif dengan memperjual-belikan minuman siap saji tersebut secara luas (Sudarma, 2009; Sukarsa, 2004:43). Diversifikasi lain pemanfaatan bahan obat tradisional dalam lontar usadha dapat dilakukan dalam bentuk minuman selamat datang (welcome drink). Saat ini, welcome drink sudah dimanfaatkan oleh hotel, namun jenisnya berkisar pada minuman dengan rasa jambu klutuk, leci atau sirzak. Diversifikasi bahan dan rasa dapat diupayakan dari tanaman obat tradisional seperti disebutkan di atas. Diversifikasi minuman selamat datang yang memenuhi rasa dan selera wisatawan tanpa menghilangkan 
rasa asali (secui naturam), akan dapat memberi kesan mendalam tentang alam dan budaya masyarakat Bali sehingga kepuasan pelanggan dapat dipastikan (Foster and Gallatin, 1986; Marimbi, 2009; Schultes, 1983; Walujo, 2004).

Selama ini, lontar Usadha atau ilmu pengobatan tradisional Bali lebih banyak digarap untuk kepentingan pengobatan (Walujo, 2004; Finn, 2003). Artinya, tanaman obat tradisional belum dijadikan konsumsi minuman sehat dan berkhasiat sehari-hari oleh masyarakat. Di samping itu, minuman sehat dan berkhasiat tinggi tersebut belum diperkenalkan kepada wisatawan sebagai minuman selamat datang. Bali memiliki sekitar 5000 (lima ribu) lontar usadha yang merupakan sumber pengobatan herbal. Sangat aneh tentunya, Bali yang memiliki banyak sumber, baik sumber tertulis tentang pengobatan maupun sumber daya alam untuk meramu jamu, justru kebanjiran produk herbal yang berasal dari luar Bali maupun mancanegara. Pada hal, kalau lontar usadha ini digarap dengan baik, maka akan dapat membantu meringankan beban ekonomi dan peluang kesehatan masyarakat (Marimbi, 2009:3).

Kepemilikansumberdayaalamsepertitanamanobattradisional tidak serta merta menyadarkan masyarakat terhadap fungsi dan kegunaan lainnya. Dalam etnobotani atau ilmu pemanfaatan berbagai jenis tumbuhan dikenal berbagai pemanfaatan, seperti obat, pangan, seks atau hiasan (Walujo, 2004). Namun, masyarakat Bali kurang memiliki kesadaran ke arah pemanfaatan tumbuhan obat sebagai bahan minuman (pangan) sehari-hari yang sehat dan berkhasiat. Hal ini dapat dimaklumi karena kepercayaan masyarakat Bali terhadap penyakit disebabkan oleh dua faktor, yaitu: faktor sekala (yang nyata) dan niskala (yang gaib). Penyakit yang disebabkan oleh faktor nyata seperti terluka kena barang tajam, masuk angin atau salah urat, sedangkan penyebab tidak nyata disebabkan oleh agen aktif berupa makhluk bukan manusia (hantu, roh atau leluhur) (Nala, 2007). Kepercayaan masyarakat seperti itu memiliki kecenderungan kuratif ketimbang preventif. Artinya, masyarakat cenderung mengobati penyakit yang dideritanya dengan meminta jasa dukun. Dukun dipercaya oleh masyarakat dapat menyembuhkan penyakit secara efektif (Foster dan Anderson, 1986). Biasanya seorang dukun tradisional Bali akan meracik obat berdasarkan lontar usadha tertentu. Bahan-bahan obat 
diramu dari berbagai tumbuhan sesuai dengan acuan lontar usadha yang dimilikinya.

Mengubah sistem kepercayaan masyarakat dari penyakitdukun-obat-penyembuhan ke konsumsi-minuman-obat-kesehatan bukan suatu keniscayaan. Menurut Teori Perubahan Perilaku (Behavior Modification Theory) bahwa sebuah perilaku dapat diubah dengan cara pembiasaan (habit formation). Namun demikian, pengubahan kebiasan harus dilakukan sejalan dengan keyakinan masyarakat Bali. Dalam Brihad Aranyanka Upanishad III 7.15 disebutkan bahwa manusia merupakan bagian dari alam yang secara spiritual dan psikologis terkait dengan elemen fisik dan biologi yang menyusun lingkungan dan semua yang berada di bawah kekuatan spiritual yang sama (Sudarma, 2009). Dengan cara demikian, maka sistem keyakinan masyarakat untuk mengonsumsi minuman sehat dan berkhasiat dari tumbuh-tumbuhan obat dapat dilakukan sebagai suatu kebiasaan atau perilaku sehari-hari. Dengan pembiasaan demikian, mereka tidak menunggu datangnya penyakit lalu berobat ke dukun untuk memeroleh kesembuhan. Sebaliknya, mereka mengonsumsi minuman sehat dan berkhasiat dari tumbuhan-tumbuhan obat untuk tidak berharap memeroleh penyakit. Secara ringkas dapat disimpulkan bahwa diversifikasi minuman obat dukun menjadi minuman siap saji akan dapat melestarikan kearifan lokal yang bersumber pada lontar usadha.

Fadiati (2012) menyebutkan makan dan minuman Indonesia sebagai kuliner tradisional. Umumnya, kuliner tradisional dikonsumsi oleh masyarakat golongan etnik di wilayah tertentu. Bahan-bahan yang digunakan diperoleh dari daerah setempat dengan racikan dan resep yang diperoleh secara turun temurun. Lebih lanjut, Fadiati mengatakan tata kemas dan penyajiannya sangat sederhana dan tidak sama dengan tata cara internasional. Makanan dan minuman tradisional memang memiliki keunggulan, yaitu bersifat alami, kaya rasa, dan tersedia sepanjang waktu (Barbara, Fried \& L-Okun, 1999). Namun, kekurangannya atau kelemahannya adalah kemasan kurang menarik, rasa terlalu khas lidah lokal, racikan tidak standar dan sebagainya (Chef William Wongso \& The Walsh Mansion, 2015).

Obat berupa jamu yang diracik berdasarkan lontar usadha tertentu yang digunakan oleh para dukun memiliki kemiripan dengan kemasan minuman tradisional. Kelemahan yang paling 
menyolok dari penyiapan minuman obat berdasarkan atas lontar usadha adalah tidak dipersiapkannya minuman obat tradisional secara ilmiah, misalnya berkaitan dengan jumlah dan dosis yang tepat. Akibatnya, pasien tersembuhkan dengan bahan obat tradisional tertentu pada suatu waktu, tetapi tidak efektif pada waktu lainnya. Di samping itu, konsumsi obat dari tumbuhan berkhasiat hanya dikonsumsi oleh masyarakat lokal.

Diversifikasi produk usadha dan pemanfaatnya perlu diperluas ke masyarakat nasional atau bahkan masyarakat internasional. Pemopuleran produk usadha kepada masyarakat luas dapat dipandang sebagai bagian dari gastro diplomasi (Leonard, 2002; Pham, 2013; Mark, 2003). Diplomasi gastro sering memeroleh sebutan lain, seperti diplomasi perut, diplomasi sepiring nasi, diplomasi makanan atau diplomasi kuliner (Fadiati, 2012). Gastro diplomasi merupakan suatu usaha kelompok, bangsa atau negara untuk mempromosikan kebudayaan mereka melalui makanan guna membentuk citra (image), globalisasi terhadap industri makanan mereka untuk menarik minat wisatawan dan membentuk hubungan baik dengan publik internasional (Pham, 2013). Menurut Zhang (2015), makanan dan minuman sudah lama dijadikan sebagai alat komunikasi antar bangsa, karena keduanya dapat merepresentasikan gagasan, nilai, identitas atau perilaku suatu bangsa. Makanan dan minuman merupakan hasil dari cipta, karsa dan karya manusia. Makanan dan minuman merupakan hasil seni yang dapat dijadikan sebagai alat integritas nasional, membentuk jati diri bangsa hingga memperoleh keuntungan dari globalisasi terhadap makanan, dalam hal ini, makanan juga dapat dijadikan alat diplomasi suatu negara untuk mencapai kepentingan nasional suatu negara (Nau, 1978; Choi, Chong, Rose, Kim, 2012).

Produk usadha dalam bentuk jamu dapat didiversifikasi menjadi minuman selamat datang (welcome drink). Penggunaan konsep kearifan lokal dapat dijadikan sebagai salah satu kekuatan, karena bahan-bahan yang digunakan untuk minuman selamat datang adalah bahan-bahan alami berasal dari tumbuhantumbuhan obat lokal. Minuman selamat datang hasil diversifikasi sebaiknya dilakukan dengan memerhatikan beberapa hal, seperti kemasan yang menarik, rasa disesuaikan dengan lidah nasional atau internasional, racikan dengan ramuan standar (Wahyuni, 2015, Chef William Wongso \& The Walsh Mansion, 2015). 
Berdasarkan atas kerangka berpikir konseptual dan empiris di atas, penelitian ini berfokus pada analisis (1) tumbuh-tumbuhan yang termuat pada lontar usadha, (2) yang digunakan oleh para dukun untuk menyembuhkan penyakit pasien, dan (3) yang dapat didiversifikasi menjadi minuman masyarakat sehari-hari dan minuman selamat datang untuk wisatawan Nusantara maupun wisatawan mancanegara.

\section{Metode}

Populasi penelitian ini adalah lontar usadha, balian, dan guru SMK serta dosen STP. Sampel lontar usadha ditetapkan secara purposif yang berjumlah 18 lontar. Sample lontar usadha dimaksud, antara lain Usadha Kalimosadha, Kuranta Bolong, Penangkal Upas, Usadha Aserep, Cukil Daki, Usadha Dalem, Usadha Ila, Usadha Cetik, Usadha Bhagawan Kasyapa, Usadha Tiwas Punggung, Usadha Penawar, Usadha Tuju, Usadha Tumbal, Usadha Gering Agung, Usadha Anda Kecacar, Usadha Pengancingan Manik, Aji Kreket, Usadha Rare, dan Taru Premana. Sampel balian terdiri atas balian usadha yang berjumlah 15 orang dari 105 balian yang tersebar di kabupaten/kota Provinsi Bali. Sedangkan, responden guru dan dosen pariwisata berjumlah 20 orang.

Desain penelitian kualitatif diterapkan dalam penelitian ini untuk mendokumentasikan unsur tanaman obat dalam usadha, dari dukun, dan unsur bahan obat tradisional yang dapat dikonversikan menjadi minuman lokal dan minuman selamat datang dari sekolah pariwisata, seperti (STP dan SMK Jurusan Tataboga). Data tentang bahan obat yang termuat dalam lontar usadha dikumpulkan dengan teknik telaah isi lontar, yaitu memilah dan memilih unsur-unsur tanaman obat yang digunakan untuk membuat loloh (jamu) untuk obat.

Data tentang tanaman obat yang digunakan oleh balian dikumpulkan dengan teknik wawancara mendalam. Wawancara dilakukan dengan para balian yang meliputi hal-hal, seperti (1) perencanaan pembuatan loloh (jamu) : mulai menentukan bahan, mencari tanaman obat, mengumpulkan bahan, membersihkan bahan; (2) melaksanakan proses pembuatan loloh (jamu), misalnya mengiris, menentukan komposisinya, lalu proses pembuatannya sampai menjadi jamu; dan (3) aturan minumnya berapa kali sehari dengan takarannya. Sedangkan, data tentang potensi 
bahan obat tradisional untuk didiversifikasi menjadi minuman masyarakat lokal dan minuman selamat datang dikumpulkan melalui kuesioner dari para guru SMK dan dosen STP Jurusan Tata Boga. Daftar pertanyaan diajukan kepada guru dan dosen pariwisata berkenaan dengan pendapatnya kemungkinan bahan obat tradisional didiversifikasi menjadi produk minuman siap saji untuk dikonsumsi oleh masyarakat lokal dan minuman selamat datang untuk wisatawan nusantara maupun mancanegara.

Data yang diperoleh dianalisis secara deskriptif kualitatif (cf. Suriasumantri, 2002). Pendokumentasian data bersumber tiga sumber berikut. Pertama, dari usadha yang tersimpan di perpustakaan Pusat Dokumentasi Kebudayaan Bali di Denpasar, Balai Bahasa Provinsi Bali di Denpasar, Perpustakaan dan Arsip Daerah Provinsi Bali di Denpasar, dan Gedong Kirtya Singaraja. Kedua, dari para dukun yang menggunakan bahan obat tradisional untuk menyembuhkan penyakit pasien. Ketiga, dari sekolah pariwisata, seperti Sekolah Tinggi Pariwisata (STP) dan Sekolah Menengah Kejuruan (SMK) Jurusan Tata Boga untuk mengetahui potensi bahan obat tradisional dikonversi menjadi minuman masyarakat lokal dan minuman selamat datang untuk wisatawan Nusantara dan mancanegara.

\section{Hasil Penelitian dan Pembahasan}

Hasil telaah isi 18 lontar usadha tentang tanaman obat yang sering digunakan oleh para dukun untuk menyembuhkan penyakit pasien ternyata sangat banyak jumlah, jenis dan bentuknya. Pemanfaatannya oleh para dukun dilakukan dalam bentuk, yaitu loloh (jamu), boreh (param), tutuh (tetes), simbuh (sembur), dan oles (oles). Namun, ketika diminta pendapatnya tentang pemanfaatan tanaman obat yang paling potensial untuk didiversifikasi menjadi minuman lokal masyarakat, maka pilihannya tertuju pada loloh (jamu). Namun, tidak semua tanaman obat yang diolah menjadi jamu enak atau baik untuk dikomsumsi. Misalnya, akar pisang busuk yang digunakan sebagai jamu untuk obat keracunan tidak enak digunakan sebagai jamu dan dijual ke masyarakat. Menurut para dukun, jamu yang dijual ke masyarakat tidak cukup hanya berasa enak, tetapi juga harus higienis, dan menarik bila dikemas.

Beberapa tanaman obat yang teridentifikasi dalam lontar usadha yang digunakan sebagai obat minum tetapi bukan minuman 
antara lain: akar silaguri; kelapa panggang, kelapa muda, isen, kunir, asam, daun kentut, belimbing buluh, belimbing besi, mengkudu, kencur, daun pancarsona, daun temen, delima putih, kayu manis, gamongan (lempuyang), jahe, jerangan, mentimun gantung, kumis kucing, temu kunci, temu tis, lengkuas, sembung, silik, semanggi gunung, temu giring, temulawak, sirih, ginten cemeng, kacemcem, sembung rambal, daun salam, tebu hitam, ketan gajih, liligundi, piduh (pegagan), jerungga, dan waru.

Tanaman obat yang digunakan sebagai obat minum yang bersumber dari dukun, yaitu adas, akar beluru, akar manis, andong, angsana, akar enau, asam jawa, bakung, daun bambu, bangle, belatung lengis, belimbing manis, belimbing wuluh, beluntas, benalu jeruk, benalu teh, beras merah, biang sunda, binahong, bintangun, bimtemu, buangit, buni, bunga matahari, camplung, kayu cang, ceguk, cendana, cermai, cincau, cocor bebek, dadap wong, daun intaran, daun jinten, daun kentut, daun salam, sirih, kumis kucing, kunir, lempuyang, lidah buaya, mahkota dewa, manggis, mengkudu, nagasari, pandan wangi, pancasona, sambiloto, samblung, selasih, semanggi gunung, sembung, sembung gunung, sirih, sirsak, srikaya, tapak liman, temu giring, temu kunci, temu lawak, temu tis, dan tingulun.

Mengingat demikian banyak bahan obat tradisional yang digunakan dukun sebagai obat minum, maka mereka diminta memikirkan bahan obat yang paling mungkin didiversifikasi menjadi minuman siap saji untuk masyarakat dengan mempertimbangkan aspek gizi, rasa, dan kemasan. Menurut responden ada 20 (duapuluh) tanaman obat yang dapat didiversifikasi menjadi minuman siap saji untuk konsumsi masyarakat lokal.

Pertanyaan serupa diajukan kepada guru-guru Sekolah Menengah Kejuruan (SMK) Pariwisata dan dosen Sekolah Tinggi Pariwisata (STP) tentang kemungkinan tanaman obat yang digunakan oleh dukun sebagai obat minum yang potensial didiversifikasi menjadi minuman selamat datang untuk wisatawan nusantara dan mancanegara, maka jawabannya sebagai berikut.

Berikut ini tanaman obat yang potensial didiversifikasi menjadi minuman masyarakat sehari-hari dan minuman selamat datang. 


\begin{tabular}{|c|c|c|c|}
\hline \multirow[b]{2}{*}{ No. } & \multicolumn{3}{|c|}{ Tanaman Obat Tradisional } \\
\hline & $\begin{array}{l}\text { Bahasa } \\
\text { Indonesia }\end{array}$ & $\begin{array}{c}\text { Bahasa Daerah } \\
\text { Bali }\end{array}$ & Bahasa Latin \\
\hline 1. & Kencur & Cekuh & Kaempferia galanga $L$. \\
\hline 2. & Temutis & Temutis & Curcuma purpuracens BL \\
\hline 3. & Lempuyang & Gamongan & Zingiber aromaticum vall \\
\hline 4. & $\begin{array}{l}\text { Belimbing } \\
\text { wuluh }\end{array}$ & Belimbing buluh & Averrhoa bilimbi L \\
\hline 5. & Sembung & Sembung & Blumea balsamifera \\
\hline 6. & Kacemcem & Cemcem & $\begin{array}{l}\text { Spondias pinnata } L \\
\text { Anacardiae }\end{array}$ \\
\hline 7. & Kunir & Kunyit & Curcuma domestica \\
\hline 8. & Mengkudu & Tibah & $\begin{array}{l}\text { Mornida citrifolia } L \\
\text { rubiaceal }\end{array}$ \\
\hline 9. & Sireh & Base & Piper betle 1 \\
\hline 10. & Belimbing besi & Belimbing besi & $\begin{array}{l}\text { Averrhwa carambola } L \\
\text { oxalidaceae }\end{array}$ \\
\hline 11. & Beras merah & Baas barak & Oriza sativa Linnf \\
\hline 12. & Kayu manis & Kayu manis & $\begin{array}{l}\text { Cinnamomun zeylanicum } \\
\text { Ness }\end{array}$ \\
\hline 13. & Ketan gajih & Ketan gajih & Oryza sativa L Alatirosa \\
\hline 14. & Jerangan & Jangu & Acorus calamus L Anaceae \\
\hline 15. & $\begin{array}{l}\mathrm{S} u \mathrm{~m} \text { a } \mathrm{n} \mathrm{g} \mathrm{g} \mathrm{i} \\
\text { gunung }\end{array}$ & Sumanggi gunung & Hydrocotyle podanta Molk \\
\hline 16. & $\begin{array}{l}\mathrm{S} \text { e } \mathrm{m} \text { b u } \mathrm{n} \mathrm{g} \\
\text { gantung }\end{array}$ & Sembung gantung & Blumea balsamifera DC.f \\
\hline 17. & Temu kunci & Temu kunci & $\begin{array}{l}\text { Bolsen bergia pandurata } \\
\text { Schbzingibergia }\end{array}$ \\
\hline 18. & Ginten cemeng & Ginten cemeng & $\begin{array}{l}\text { Cuminum cyminum L. } \\
\text { umbelliferaceae }\end{array}$ \\
\hline 19. & Beluntas & Beluntas & Plucea undica \\
\hline 20. & Silik & Srikaya & Annona squamoza \\
\hline
\end{tabular}




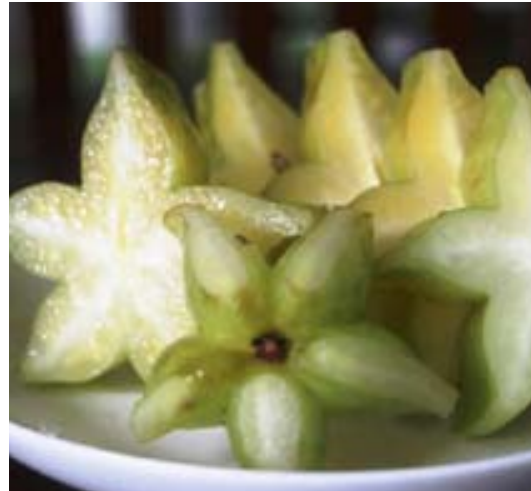

Buah Belimbing

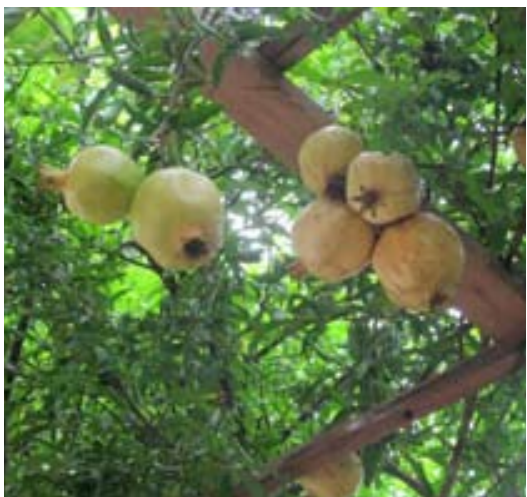

Buah Delima

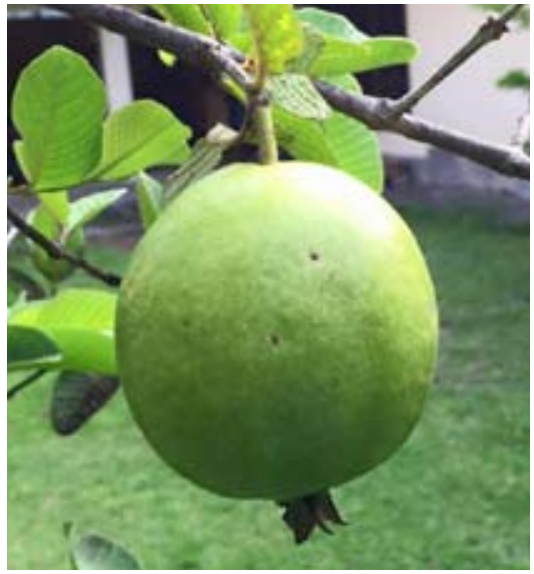

Jambu

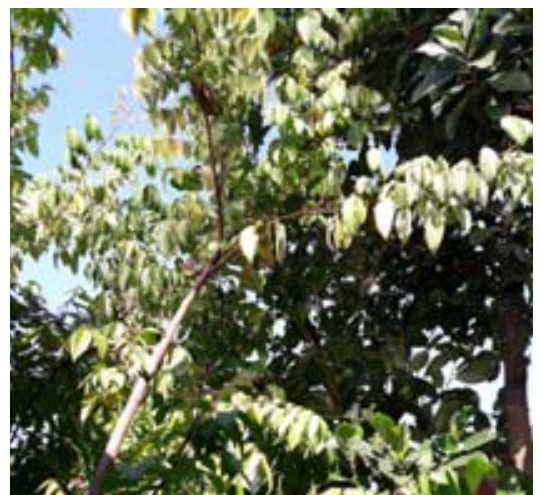

Pohon Belimbing

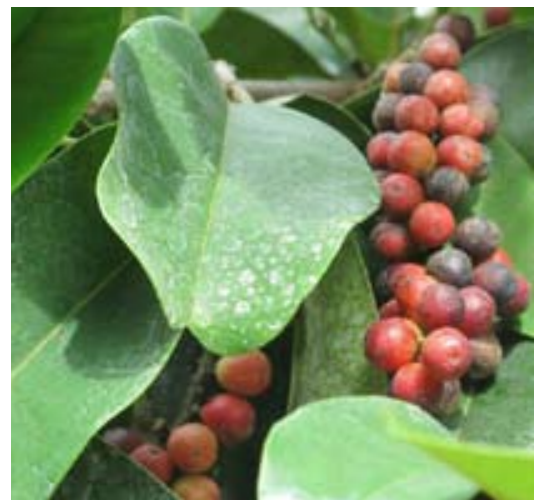

Buni

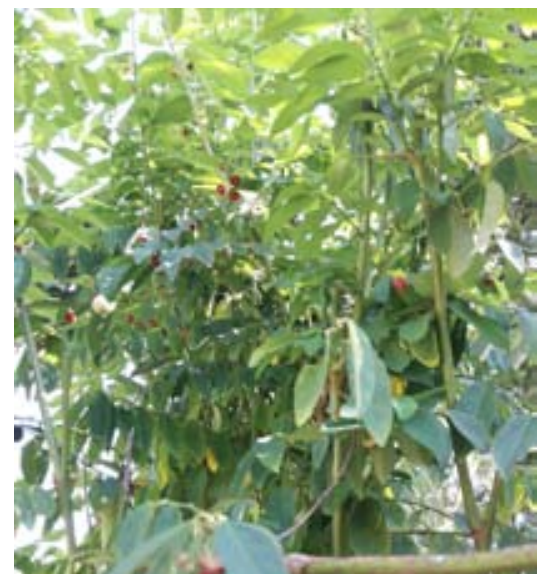

Kayumanis 


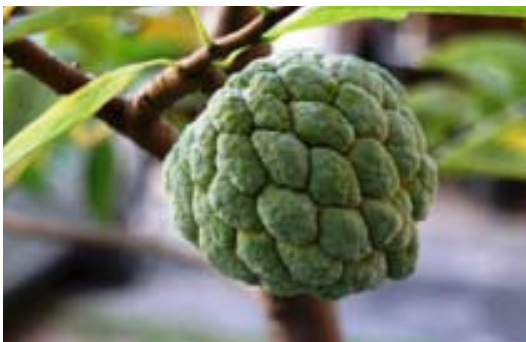

Silik

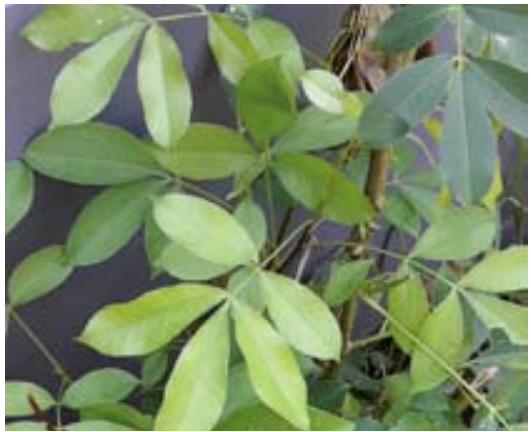

Kacemcem

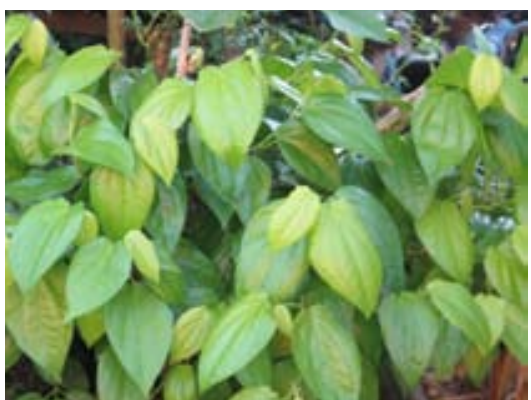

Pinang

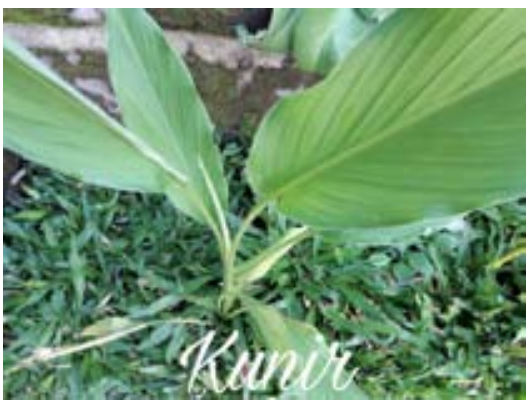

Kunir

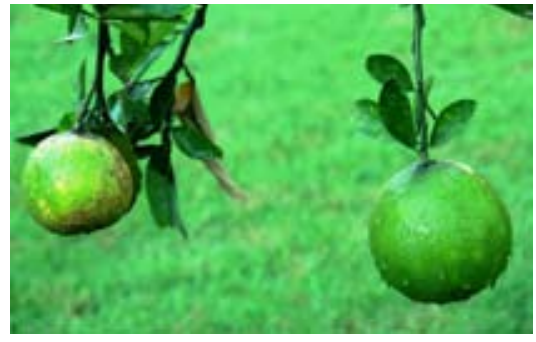

Jerungga

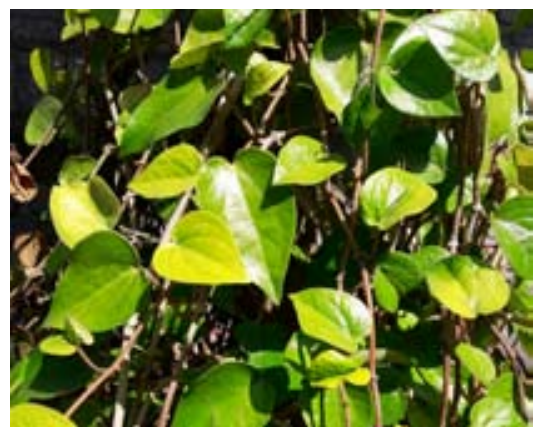

Sirih

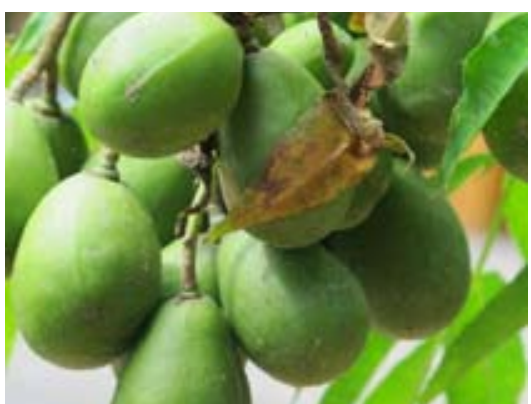

Kedongdong

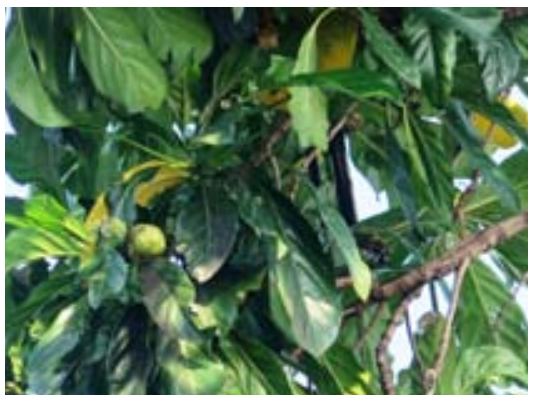

Mengkudu 
Tanaman obat yang termuat dalam lontar usadha dan yang digunakan para dukun untuk pengobatan pasien sangat banyak jumlah danjenisnya. Pemanfaatan tanamanobatsebagaijamu sangat sering oleh dukun. Hal ini dijelaskan bahwa jamu dapat segera diminum dan segera beredar di seluruh tubuh. Namun demikian, tidak semua obat minum dapat didiversifikasi menjadi minuman masyarakat atau minuman selamat datang untuk wisatwan nusantara maupun mancanegara. Biasanya obat minum rasanya pahit, sepet atau pedas. Untuk memproses obat minum menjadi minuman yang enak dan berkhasiat untuk masyarakat, wisatawan nusantara dan mancanegara perlu memerhatikan beberapa hal, antara lain (1) Pengolahan bahan minuman secara higienis dan tidak merusak zat gizi yang dikandungnya; (2) Memenuhi komposisi gizi yang tepat; (3) Mengurangi campuran rasa yang memiliki rasa tajam; (4) Penyajian minuman harus menarik; (5) Peralatan saji dan peralatan lainnya yang tidak menghilangkan unsur tradisional; (6) Penyajian yang tepat sesuai dengan hidangan saat makan pagi, siang, atau malam; dan (7) Rancangan kemasan yang menarik dan praktis.

Selain itu, aspek kualitas minuman tradisional harus memenuhi kriteria, seperti (1) Organoleptik, yaitu: minuman harus memiliki rasa enak, aroma harum, tekstur yang sesuai, warna menarik, penyajian menarik, disesuaikan dengan selera yang mengkonsumsinya; (2) Kimiawi, yaitu: minuman tidak mengandung bahan kimia tambahan seperti bahan pelezat, bahan pengempal, bahan penambah aroma kimia, bahan pengemulsi kimia, bahan pengawet sehingga benar-benar mewujud minuman alami; (3) Gizi, yaitu: minuman seharusnya mengandung unsurunsur gizi yag diperlukan tubuh; dan (4) Mikrobiologis, yaitu: minuman tidak mengandung jamur, kapang, atau bakteri, sehingga sehat untuk dikonsumsi. Dengan memerhatikan kriteria dan syarat-syarat di atas, minuman yang dibuat dari tanaman obat dapat diterima oleh berbagai bangsa di dunia dan sebagai modal diplomasi melalui bidang minuman tradisional.

\section{Simpulan dan saran}

Tanaman obat yang termuat dalam lontar usadha dan yang digunakan oleh dukun sebagai obat minum sangat banyak jumlah dan jenisnya. Namun, tanaman obat yang potensial didiversifikasi 
menjadi minuman untuk masyarakat lokal sehari-hari dan minuman selamat datang untuk wisatawan Nusantara dan mancanegara dipilih 20 jenis tanaman obat. Agar proses diversifikasi tanaman obat yang digunakan sebagai obat minum dapat didiversifikasi menjadi minuman siap saji atau minuman selamat datang dan memomulerkan secara luas, maka beberapa pertimbangan penting perlu diambil.

1) Pemanfaatan teknologi tepat guna dan reka minuman dalam industri pangan guna memperbaiki citra minuman tradisional sangat diperlukan agar dapat memenuhi selera masyarakat lokal maupun nasional dan internasional.

2) Menghimbau pihak manajemen hotel dan restoran untuk dapat menyajikan minuman tradisional Bali pada saat makan pagi, siang, malam atau peristiwa besar, seperti perkawinan atau pesta-pesta ulang tahun.

3) Meningkatkan cara penyajian minuman tradisional Bali dengan memanfaatkan peralatan hasil teknologi dengan tetap mempertahankan ciri keasliannya sehingga lebih menarik.

4) Meningkatkan mutu fisik, mutu gizi maupun cita rasa, penataan minuman tradisional saat akan disajikan, dan meningkatkan sanitasi lingkungan tempat usaha.

5) Meningkatkan promosi dan pemasaran produk minuman tradisional Bali secara intensif dengan kemasan promosi yang menarik.

\section{Daftar pustaka}

Barbara F; Okum;Jane Fried; Marcia L-Okun. 1999. Understanding Diversity: A Learning-

Chef William Wongso \& The Walsh Mansion. 2015. [online] available at: http://www.embassyofindonesia.org/wordpress/wpcontent/uploads/2015/05/PR-Passport-DC-fin.pdf [accessed 22 Aug. 2016].

Choi, Y. Cho, S. Chong, E, Rose, H. Kim, H. 2012. Taste the Influence:The Spread of Gastro-diplomacy in Asia. Transition and Regime Changes 35 (2), 5-13

Fadiati, Ari. 2012. Mengelola Jasa Boga Yang Sukses. Bandung: Rosda Karya.

Foster, George M dan Anderson Barbara. Gallatin. 1986. Medical 
Anthropology Diterjemahkan oleh Priyanti Pakan Suryadarma dan Meutia F. Hatta Swasono. Jakarta: UI Press.

Marimbi, Hanum. 2009. Sisiologi dan Antropologi Kesehatan. Yogyakarta: Nuha Medika.

Nala, I Gusti Ngurah. 2007. Usadha di Bali dalam Usadha Majalah Kesehatan. Denpasar: Paramita.

Nau, H.R. 1978. The diplomacy of world food: Goals, Capabilities, Issues and Arenas. International Organization, 32 (3), 775-809

Oka, Ida Bagus. 2002. Potensi dan Tantangan Masa Depan Dalam Pengembangan Pariwisata Budaya di Bali dalam Menuju Terwujudnya Ilmu Pariwisatadi Indonesia.Denpasar : Program Studi Kajian Budaya Universitas Udayana Bali.

Pham, M. J. 2013. Food as communication: A case study of South Korea's Gastrodiplomacy. Journal of International Service, 22(1), $1-22$

Schultes, R.E. and Richard Spuce. 1983. An early etnhobotanish and explorer of the northwest Amazon and Northern Andes, Journal of Ethnobiology 3: 139 - 147

Sudarma, Momon. 2009. Sosiologi Kesehatan. Jakarta: Salemba Medika.

Sujana, dkk. 2014. Pengembangan Ekonomi Kreatif Berbasis Warga Belajar dalam Mendukung Kepariwisataan di Bali. Laporan Penelitian MP3EI Undiksha Tidak Dipublikasikan.

Sukarsa, I Made. 2004. Sisi Ekonomi Sebuah Upacara dalam Prosiding Seminar Konservasi Tumbuhan Upacara AgamaHindu. Candikuning: Bagian Proyek Pelestarian, Penelitian dan Pengembangan Flora Kawasan Timur Indonesia UPT Balai Konservasi Tumbuhan Kabun Raya "Eka Akarya" Bali-LIPI.

Sukerti, Ni Wayan dkk. 2016. Reinvetarisasi Makanan Tradisional Buleleng sebagai Upaya Pelestarian Seni Kuliner Bali dalam Jurnal Ilmu Sosial $\mathcal{E}$ Humaniora Volume 5, Nomor 1 April 2016.

Suriasumantri, Jujun S. 2002. Pariwisata sebagai Sebuah Disiplin Ilmu. Sebuah Pendekatan Kefilsafatan dalam Pengembangan Pariwisata Budaya di Bali dalam MenujuTerwujudnya Ilmu Pariwisata di Indonesia. Denpasar: Program Studi Kajian Budaya Universitas Udayana.

Walujo, Eko Baroto. 2004. Tumbuhan Upacara Adat Bali dalam Perspektif Penelitian Etnobotani dalam Prosiding Seminar Konservasi Tumbuhan Upacara Agama Hindu. Candikuning Bagian Proyek Pelestarian Penelitian dan Pengembangan Flora Kawasan Timur Indonesia 
: UPT Balai Konservasi Tumbuhan Kebun Raya "Eka Karya Bali - LIPI.

Wahyuni., T. 2015. (25 November). CNN Indonesia. Retrieved from http://www. scnnindonesia.com/gaya-hidup/20151124173920262-93765/punya-rendang-terenak-kuliner-indonesia-masihterbelakang/

Zhang, J. 2015. The Foods of the Worlds: Mapping and Comparing Contemporary Gastrodiplomacy Campaigns. Journal of Communication, 9, 568-591. 